\title{
Photosynthetic responses to temperature and light of Antarctic and Andean populations of Colobanthus quitensis (Caryophyllaceae)
}

\author{
Respuestas fotosintéticas a la temperatura y a la luz de poblaciones antárticas \\ y andinas de Colobanthus quitensis (Caryophyllaceae)
}

\author{
ÁNGELA SIERRA-ALMEIDA ${ }^{1,3}$, M. ANGÉLICA CASANOVA-KATNY ${ }^{1,2^{*}}$, LEÓN A. BRAVO $^{2}$, \\ LUIS J. CORCUERA ${ }^{2} \&$ LOHENGRIN A. CAVIERES $^{1,3}$
}

\begin{abstract}
${ }^{1}$ ECOBIOSIS, ${ }^{2}$ Laboratorio de Fisiología Vegetal, Departamento de Botánica, Universidad de Concepción, Concepción, Chile. ${ }^{3}$ Instituto de Ecología y Biodiversidad (IEB), Casilla 653, Santiago, Chile;

* e-mail for correspondence: angecasanova@udec.cl
\end{abstract}

\begin{abstract}
Colobanthus quitensis (Kunth, 1831) Bartling (Caryophyllaceae) is characterized by a wide latitudinal distribution, ranging between the tropical high Andes and the Antarctic Peninsula. Although both habitat types are characterized by cold and freezing temperatures, important microclimatic differences exist during the growing season. Hence, important differences in the response of the photosynthetic apparatus to abiotic factors could be expected between Antarctic and Andean populations of C. quitensis. We studied the relationship between net photosynthesis, leaf temperature and light intensity in two populations of $C$. quitensis, one from La Parva in the Andes of central Chile and the other from King George Island, in the Maritime Antarctic. Plants from both populations were grown in the laboratory at $15{ }^{\circ} \mathrm{C}$ under $250 \mu \mathrm{mol}$ photons $\mathrm{m}^{-2} \mathrm{~s}^{-1}$, with a $16 / 8 \mathrm{~h}$ light/dark photoperiod. Twenty plants (about two months old) of each population were transferred to a $4{ }^{\circ} \mathrm{C}$ chamber with the same light and photoperiod conditions as above to assess the photosynthetic acclimation capacity. At $15{ }^{\circ} \mathrm{C}$, populations differed in their optimum leaf temperature for photosynthesis, being $24.0{ }^{\circ} \mathrm{C}$ in individuals from the Andes and $18.6{ }^{\circ} \mathrm{C}$ in individuals from the Antarctic. In contrast, Antarctic individuals showed the highest net photosynthesis rate under both temperature treatments, with the lowest light compensation and saturation points. Antarctic individuals had higher photosynthetic activity at lower temperatures compared to individuals from the Andes. Our results suggest that $C$. quitensis has adapted photosynthetic performance of individuals growing in different localities to the prevailing climatic conditions. Differences in photosynthetic responses to temperature and light are discussed in relation to ecotypic differentiation between two populations studied.
\end{abstract}

Key words: photosynthesis, Colobanthus quitensis, optimum leaf temperature, light intensity.

\section{RESUMEN}

Colobanthus quitensis es una especie ampliamente distribuida, que crece desde los Andes tropicales hasta la Península Antártica. A pesar de que ambos hábitats se caracterizan por ser fríos y con temperaturas congelantes, existen importantes diferencias microclimáticas entre estos hábitats durante el período de crecimiento. Por ello, sería esperable encontrar importantes diferencias en la respuesta del aparato fotosintético a factores abióticos entre poblaciones antárticas y andinas de C. quitensis. Estudiamos la relación de la fotosíntesis neta con la temperatura foliar y la intensidad lumínica en dos poblaciones de $C$. quitensis, una proveniente de La Parva en Los Andes de Chile central y la otra de la Isla Rey Jorge, en la Antártica marítima. Plantas de ambas poblaciones fueron crecidas en laboratorio a $15{ }^{\circ} \mathrm{C}$ y $250 \mu \mathrm{mol}$ fotones $\mathrm{m}^{-2} \mathrm{~s}^{-1}$, con un fotoperíodo de $16 / 8 \mathrm{~h}$ luz/oscuridad. Veinte plantas de cada población fueron transferidas a una cámara a $4{ }^{\circ} \mathrm{C}$, con las mismas condiciones de luz y fotoperíodo antes mencionadas, de modo de evaluar la capacidad de aclimatación de la fotosíntesis. A $15{ }^{\circ} \mathrm{C}$, las poblaciones presentaron diferencias en su temperatura foliar óptima para la fotosíntesis. Estos óptimos fueron $24,0{ }^{\circ} \mathrm{C}$ en individuos provenientes de los Andes y $18,6^{\circ} \mathrm{C}$ en individuos de la Antártida. En contraste, los individuos antárticos mostraron la más alta tasa de fotosíntesis neta bajo ambos tratamientos de temperatura, con puntos de compensación y saturación más bajos. Los individuos antárticos tuvieron mayor capacidad fotosintética a menores temperaturas que los individuos andinos. Nuestros resultados sugieren que $C$. quitensis ha adaptado el desempeño fotosintético de individuos creciendo en diferentes localidades a las condiciones climáticas predominantes en dichas localidades. Las diferencias en las respuestas fotosintéticas a la temperatura y a la luz son discutidas en relación a la diferenciación ecotípica entre las dos poblaciones estudiadas.

Palabras clave: fotosíntesis, Colobanthus quitensis, temperatura óptima, intensidad lumínica. 


\section{INTRODUCTION}

Alpine and polar habitats are characterized by low temperatures, strong winds and short growth periods (Kappen 1999, Körner 1999). Plants in these habitats must be adapted to harsh environmental conditions (Billing \& Mooney 1968, Bliss 1971, Körner 1999). Despite the fact that both habitat types are predictably cold, important differences occur in thermal and radiation regimes during the growing season (Bliss 1956). In alpine habitats at lower latitudes, the growing season is typically longer, warmer, and with higher irradiance than at polar latitudes (Bliss 1956, Billings \& Mooney 1968, Körner 1999). In addition, alpine environments have low partial pressure of $\mathrm{CO}_{2}$ and $\mathrm{O}_{2}$ and extreme fluctuations in daily temperature (Billings \& Mooney 1968, Friend \& Woodward 1990).

Some plant species are able to grow in both, alpine and polar habitats (Mooney \& Billings 1961, Mooney 1963, Mooney \& Johnson 1965) and it has been shown that this capacity mainly reflects their ability to locally adapt their functioning to the prevailing environmental conditions (ecotype formation). For instance, sharp physiological differences have been found between arctic and alpine populations of Oxyria digyna in North America, where, despite photosynthetic rates being similar between both populations, optimum temperature for maximum photosynthesis was lower in arctic populations (Mooney \& Billings 1961). Furthermore, while the arctic populations showed a higher dark respiration rate, light saturation points of photosynthesis were higher in the alpine populations (Mooney \& Billings 1961). Similar results have been reported for other artic-alpine ecotypes in species such as Thalictrum alpinum, Polygonum bistortoides and Solidago virgaurea (Mooney \& Billings 1961, Mooney 1963, Mooney \& Johnson 1965, Björkman 1966). However, other studies have not found evidence for ecotypic differentiation of photosynthetic parameters (e.g., optimum temperature, maximum photosynthetic rate) within species (Chapin \& Oechel 1983), indicating that ecotypic differentiation of the photosynthetic apparatus is not a universal phenomenon.

The pearlwort Colobanthus quitensis (Kunth) Bartl (Caryophyllaceae) is a widely distributed perennial herb growing from
Mexico $\left(17^{\circ} \mathrm{N}\right)$, throughout the Andes of South America, to the Southern Antarctic Peninsula $\left(68^{\circ} \mathrm{S}\right)$ and from 0 to $4,200 \mathrm{~m}$ of altitude. (Moore 1970, Smith 2003). In Chile, $C$. quitensis is found along the Andes, typically in bogs situated at high altitudes in the north, but closer to sea level at polar latitudes (More 1970, Hoffmann et al. 1998). Notwithstanding, it can be found at $500 \mathrm{~m}$ elevation in some subAntarctic Islands (Edwards \& Smith 1988). Colobanthus quitensis forms small, compact cushions.

Most of the information about the ecophysiology of Colobanthus quitensis and its adaptations to low temperature environments come from field studies of Antarctic populations. It has been shown that the photosynthetic apparatus of this species is well adapted to the Antarctic climate, being able to maintain relatively high photosynthetic rates at low temperature (Xiong et al. 1999). Gianoli et al. (2004) found morphological differences when plants collected in the Andes of central Chile (ca. $33^{\circ} 19^{\circ} \mathrm{S}$ ) and in the Antarctic Peninsula (ca. $62^{\circ} 10^{\circ} \mathrm{S}$ ) were grown in a common garden experiment, suggesting local differentiation or ecotype formation.

Recently, Casanova-Katny et al. (2006) reported that in the central Chilean Andes this species experiences wide daily temperature fluctuations during the summer (ranging from 0 to $22{ }^{\circ} \mathrm{C}$ ) and high photosynthetic photon flux density (PPFD) levels (> 2,000 $\mu \mathrm{mol}$ photons $\mathrm{m}^{-}$ $\left.{ }^{2} \mathrm{~s}^{-1}\right)$. In contrast, in the Maritime Antarctic (King George Island), mean air temperature fluctuates between -2 and $6{ }^{\circ} \mathrm{C}$ during the summer (Gianoli et al. 2004). PPFD conditions are variable, with overcast days being frequent, and with few days reaching light intensities near to $2,000 \mu \mathrm{mol}$ photons $\mathrm{m}^{-2} \mathrm{~s}^{-1}$ (Day et al. 1999, Alberdi et al. 2002). These environmental differences suggest that Andean populations should attain physiological characteristics in their photosynthetic apparatus different to those of Antarctic populations.

The aim of the present study was to characterize and compare the photosynthetic responses to temperature and light intensity of two populations of $C$. quitensis from the Andes of central Chile and the maritime Antarctic, in King George Island. We hypothesised (1) that plants from the Antarctic require lower temperature to reach maximum photosynthesis 
compared to that from the Andes and (2) that plants from the Andes have higher light saturation and compensation points than those from the maritime Antarctic. To assess the acclimation potential of photosynthesis in both populations, we additionally studied their photosynthetic responses to light intensity and temperature.

\section{MATERIAL AND METHODS}

\section{Plant material}

Colobanthus quitensis plants (20 plants, about $10 \mathrm{~mm}$ height, vegetative stage) were collected at sea level, in the vicinity of Arcktowski Station, King George Island, Maritime Antarctic $\left(62^{\circ} 10^{\prime} \mathrm{S}, 58^{\circ} 29^{\prime} \mathrm{W}\right)$. Plants were transported in a cooler in plastic bags to the laboratory at University of Concepción in the austral summer of 1997. One week later, they were planted and reproduced in the laboratory at $15{ }^{\circ} \mathrm{C}$. For vegetative reproduction, lateral stems without roots were manually detached and planted in plastic pots $(20 \times 12 \times 8 \mathrm{~cm}, 20$ plants per pot) filled with a (3:1) top soil/peat mixture and grown at photosynthetic photon flux density (PPFD) of $250 \mathrm{mmol}$ photons $\mathrm{m}^{-2}$ $\mathrm{s}^{-1}$ at the top of the canopy under a $16 / 8 \mathrm{~h}$ light/ dark period. The light source was provided by cool-white fluorescent tubes F40CW (General Electric). Plants were fertilized with Phostrogen (Solaris, NPK:14-10-27) using 0.2 $\mathrm{g} \mathrm{L} \mathrm{L}^{-1}$ once every 2 weeks. Under these conditions nearly all plants survived. To preserve the genetic constitution, no sexual reproduction was allowed.

Andean plants of Colobanthus quitensis (20 plants about $15 \mathrm{~mm}$ height, vegetative stage) were collected at Cerro La Parva $\left(33^{\circ} 19^{\prime} \mathrm{S}\right.$, $70^{\circ} 17^{\prime} \mathrm{W} ; 2,800 \mathrm{~m}$ of altitude) in March 2001. Colobanthus quitensis was collected from bogs where the dominant species are large tightly knit cushion plants such as Patosia clandestina, Oxychloe andina, and Werneria spp. Plants were reproduced vegetatively in plastic pots, using a top soil:peat mixture (3:1) and maintained at $15^{\circ} \mathrm{C}$ in a growth chamber (Forma Scientific Inc.) under identical light and photoperiod conditions as above. Plants were fertilized with Phostrogen (Solaris, NPK:14-1027) using $0.2 \mathrm{~g} \mathrm{~L}^{-1}$ once every 2 weeks. At the beginning of the experiment, all plant (40 pots) were growing at $15{ }^{\circ} \mathrm{C}$ and $250 \mu \mathrm{mol}$ photons $\mathrm{m}^{-2} \mathrm{~s}^{-1}, 16 / 8 \mathrm{~h}$ day/night photoperiod. After two months, half of the pots of each group of plants were placed in another climatic chamber at $4{ }^{\circ} \mathrm{C}$ for three weeks until photosynthesis measurements were carried out. Consequently, the experimental design consisted of two population sources (Andes and Antarctic) grown at two temperatures $\left(4\right.$ and $\left.15^{\circ} \mathrm{C}\right)$.

\section{Temperature dependence of net photosynthesis}

Gas exchange measurements at different temperatures were carried out on five plants from each population and temperature treatments. Whole plants (one per pot) were used for the measurements with three to five attached leaves. Net photosynthesis $\left(\mathrm{P}_{\mathrm{n}}\right)$ was measured with a portable infrared gas analyzer (IRGA, CIRAS-1, PP-Systems Haverhill, Massachusetts, USA), which was programmed to increase leaf chamber temperature from $0^{\circ}$ to $32{ }^{\circ} \mathrm{C}\left(2{ }^{\circ} \mathrm{C}\right.$ every $\left.6 \mathrm{~min}\right)$ and to measure $\mathrm{P}_{\mathrm{n}}$ at the end of each of these periods. Constant PPFD $\left(800 \mu \mathrm{mol} \mathrm{m} \mathrm{m}^{-2} \mathrm{~s}^{-1}\right)$ and $\mathrm{CO}_{2}\left(360 \mu \mathrm{L} \mathrm{L}^{-1}\right)$ concentrations were used throughout the measurements. Photosynthetic rate was calculated on leaf area basis and the optimum temperature for maximum photosynthesis rate $\left(A_{\max }\right)$ was estimated by feeding the leaftemperature versus $\mathrm{P}_{\mathrm{n}}$ data to a second-order polynomial, and calculating its first derivate (Cavieres et al. 2000). The sensitivity of photosynthesis to temperature changes was estimated by calculating the $\mathrm{Q}_{10}$ temperature coefficient for each measured individual. $\mathrm{Q}_{10}$ is the empirically measured change in the rate of a reaction for an alteration in temperature of 10 ${ }^{\circ} \mathrm{C}$ and was obtained according to Mohr \& Schopfer (1995).

\section{Light response curves}

Another five individuals from each population and temperature treatments were used to obtain photosynthetic response curves to different PPFDs. Gas exchange measurements were made at $15^{\circ} \mathrm{C}$ (close to the optimum according to Xiong et al. (1999) for C. quitensis) and the IRGA was programmed to increase the PPFD from 0 to $2.000 \mu \mathrm{mol}$ photons $\mathrm{m}^{-2} \mathrm{~s}^{-1}(100 \mu \mathrm{mol}$ photons $\left.6 \mathrm{~min}^{-1}\right) . \mathrm{P}_{\mathrm{n}}$ values were fitted to a 
light intensity response curve according to Lambers et al. (1998). From each curve both the light compensation point $\left(\mathrm{I}_{\mathrm{c}}\right)$ and the light saturation point $\left(I_{s}\right)$ were estimated. $I_{c}$ and $I_{s}$ were calculated for each individual measured and $\mathrm{P}_{\mathrm{n}}$ was expressed on leaf area basis; dark respiration $\left(R_{d}\right)$ was obtained through gas exchange measurements after covering the leaf chamber for $20 \mathrm{~min}$.

\section{Data analyses}

Two way-ANOVAs were used to test significant differences in the parameters calculated from gas exchange measurements at different temperatures and PPFD levels (optimum temperature for photosynthesis, $I_{c}$,
$\mathrm{I}_{\mathrm{s}}$ ), where population (Antarctic and Andes) and temperature treatment $\left(4^{\circ}\right.$ and $\left.15^{\circ} \mathrm{C}\right)$ were considered independent factors. When ANOVA indicated significant effects of one or more factors $(\mathrm{P}<0.05)$, a Tukey a-posteriori test was applied.

\section{RESULTS}

Generally, at both temperature treatments (4 and $\left.15{ }^{\circ} \mathrm{C}\right), C$. quitensis individuals from the Antarctic showed higher $\mathrm{A}_{\max }$ than individuals from the Andes. $\left(\mathrm{A}_{\max }\right)$ fluctuated between 4.0 $4.7 \mu \mathrm{mol} \mathrm{CO}_{2} \mathrm{~m}^{-2} \mathrm{~s}^{-1}$ in the Antarctic individuals and between 2.0-3.1 $\mu \mathrm{mol} \mathrm{CO}_{2} \mathrm{~m}^{-2}$ $\mathrm{s}^{-1}$ in the Andean individuals (Fig. 1, Table 1).

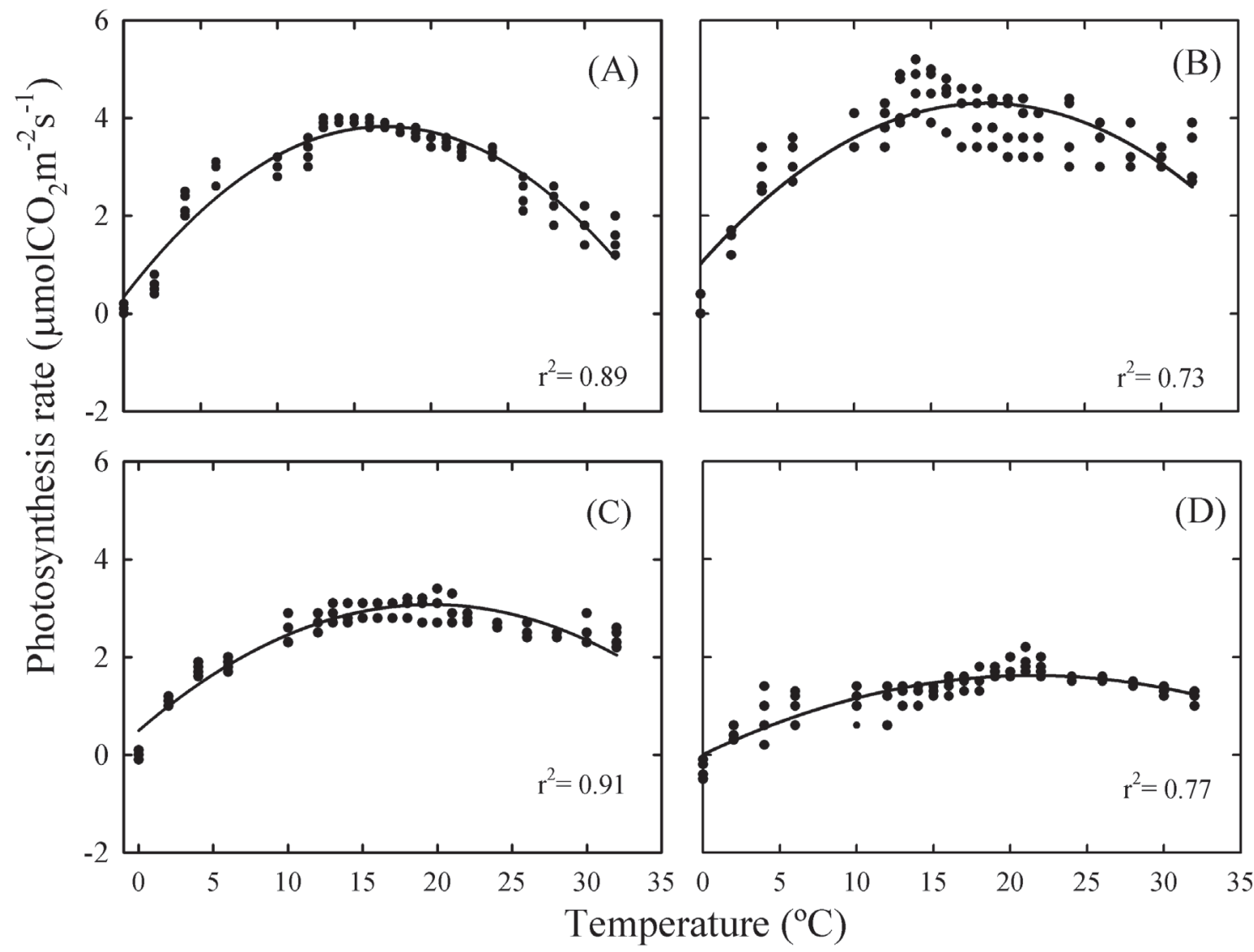

Fig. 1: Dependence of net photosynthesis on temperature in two populations of different origin (Antarctic and Andes) of Colobanthus quitensis. Plants were grown at $15{ }^{\circ} \mathrm{C}\left(250 \mu \mathrm{mol}\right.$ photons $\mathrm{m}^{-2}$ $\mathrm{s}^{-1}, 16 / 8$ day/night $)$ and exposed three weeks at $4{ }^{\circ} \mathrm{C}\left(250 \mu \mathrm{mol}\right.$ photons $\mathrm{m}^{-2} \mathrm{~s}^{-1}, 16 / 8 \mathrm{~h}$ day/night $)$ : Antarctic ecotype at $4{ }^{\circ} \mathrm{C}(\mathrm{A})$ and $15{ }^{\circ} \mathrm{C}(\mathrm{B})$, Andean ecotype at $4{ }^{\circ} \mathrm{C}(\mathrm{C})$, and at $15{ }^{\circ} \mathrm{C}(\mathrm{D})$.

Fotosíntesis neta dependiente de la temperatura en dos poblaciones de diferente origen (Antártida y Andes) de Colobanthus quitensis. Las plantas crecieron a $15{ }^{\circ} \mathrm{C}\left(250 \mu \mathrm{mol}\right.$ fotones $\mathrm{m}^{-2} \mathrm{~s}^{-1}, 16 / 8$ día/noche) y expuestas a $4{ }^{\circ} \mathrm{C}$ durante tres semanas $\left(250 \mu \mathrm{mol}\right.$ fotones $\mathrm{m}^{-2} \mathrm{~s}^{-1}, 16 / 8$ día/noche): ecotipo antártico a $4{ }^{\circ} \mathrm{C}(\mathrm{A})$ y $15{ }^{\circ} \mathrm{C}(\mathrm{B})$, ecotipo andino a $4{ }^{\circ} \mathrm{C}(\mathrm{C})$ y (D) a $15{ }^{\circ} \mathrm{C}$. 
Temperature treatment and population showed significant effects on optimum temperature for $\mathrm{A}_{\max }$ (Table 1). Andean individuals showed the highest optimum temperature for $\mathrm{P}_{\mathrm{n}}$ with an average of 24 and $20{ }^{\circ} \mathrm{C}$ in plants at 15 and 4 ${ }^{\circ} \mathrm{C}$, respectively (Table 1 ). In individuals from the Antarctic, optimum temperatures were lower $\left(18.6\right.$ and $17{ }^{\circ} \mathrm{C}$ at 15 and $4{ }^{\circ} \mathrm{C}$, respectively) (Fig. 1, Table 1).

Temperature range for 95 and $50 \%$ of photosynthesis was calculated according to Körner \& Diemer (1995). Independently of the geographical origin, the temperature range for the $95 \%$ of $\mathrm{A}_{\max }$ was similar in individuals at both treatment temperatures. However, whereas in the Antarctic population this temperature range fluctuated between $10-20{ }^{\circ} \mathrm{C}$, a wider range was found in the Andes populations (6.6$26.8{ }^{\circ} \mathrm{C}$ for plants at $4{ }^{\circ} \mathrm{C}$, and $11.1-30.1{ }^{\circ} \mathrm{C}$ for plants at $15{ }^{\circ} \mathrm{C}$ ). Likewise, the temperature range for $50 \%$ of $\mathrm{A}_{\max }$ was larger for the Andean population, ranging from 2.6-3.9 to ca. $40{ }^{\circ} \mathrm{C}$ (Table 1). $\mathrm{Q}_{10}$ values did not differ between the two populations at $15{ }^{\circ} \mathrm{C}$ (ca. 1.4), but at $4{ }^{\circ} \mathrm{C}$ the Antarctic individuals showed the higher $\mathrm{Q}_{10}(1.8)$, indicating higher sensitivity to temperature changes in this population (Fig. 1, Table 1).

$P_{n}$ values at different light intensities fitted well to formal light response curves $\left(\mathrm{R}^{2}>0.9\right)$
(Fig. 2). Individuals from the Antarctic showed lower light compensation points $\left(I_{c}\right)$ than individuals from the Andes at both temperature treatments (Table 2). Significant differences were also found for the light saturation points $\left(I_{S}\right)$ between both populations, being $I_{s}$ values higher in Andean individuals compared to Antarctic individuals (Table 2) at the two temperature teatments. $A_{\max }$ in individuals from the Antarctic was higher than in their Andean counterparts, with the latter having high dark respiration rates at low temperatures (Table 2), being $R_{d}$ values higher after cold treatments only in Antarctic plants.

\section{DISCUSSION}

Our results were consistent with the hypothesis that the optimum temperature for maximal photosynthesis would be higher in Colobanthus quitensis individuals from a high elevation location (La Parva in the Andes) than those from a polar habitat (King George Island), independently of the temperature at which plants were grown. While optimum temperature of photosynthesis in individuals from La Parva was $20{ }^{\circ} \mathrm{C}$ and $24{ }^{\circ} \mathrm{C}$ when growing at $4-15{ }^{\circ} \mathrm{C}$, respectively, these optima were $17-18{ }^{\circ} \mathrm{C}$ for plants from the Antarctic at $4-15{ }^{\circ} \mathrm{C}$,

Photosynthetic parameters obtained from temperature responses curves. Net photosynthesis rate measurements were carried out on two ecotypes of Colobanthus quitensis (Antarctic and Andes) growing at $15^{\circ} \mathrm{C}\left(250 \mu \mathrm{mol}\right.$ photons $\mathrm{m}^{-2} \mathrm{~s}^{-1}, 16 / 8 \mathrm{~h}$ day/night $)$ and after three weeks of low temperature treatments at $4{ }^{\circ} \mathrm{C}\left(250 \mu \mathrm{mol}\right.$ photons $\mathrm{m}^{-2} \mathrm{~s}^{-1}, 16 / 8 \mathrm{~h}$ day/night $): \mathrm{T}_{\text {opt }}=$ temperature of photosynthetic optimum $\left({ }^{\circ} \mathrm{C}\right), \mathrm{Q}_{10}=$ temperature coefficient, $\mathrm{A}_{\max }=$ maximum photosynthetic rate $\left(\mu \mathrm{mol} \mathrm{CO} \mathrm{CO}^{-2} \mathrm{~s}^{-1}\right), 95 \% \mathrm{~A}_{\max }$ and $50 \% \mathrm{~A}_{\max }=$ temperature range for 95 and $50 \%$ of maximum photosynthetic rate $\left({ }^{\circ} \mathrm{C}\right)$. Values are means $(n=5) \pm$ SE. Different letters indicate statistical differences after Tukey-tests

Parámetros fotosintéticos obtenidos de las curvas de respuesta a la temperatura. Las mediciones de tasa de fotosíntesis neta se realizaron en dos ecotipos de Colobanthus quitensis (Antártica y Andes) crecidos a $15^{\circ} \mathrm{C}\left(250 \mu \mathrm{mol}\right.$ fotones $\mathrm{m}^{-2} \mathrm{~s}^{-1}, 16 / 8$ h día/noche) y después expuestos a un tratamiento de baja temperatura por tres semanas a $4{ }^{\circ} \mathrm{C}\left(250 \mu \mathrm{mol}\right.$ fotones $\mathrm{m}^{-2} \mathrm{~s}^{-1}$, 16/8 h día/noche): $\mathrm{T}_{\mathrm{opt}}=$ temperatura óptima para la fotosíntesis $\left({ }^{\circ} \mathrm{C}\right), \mathrm{Q}_{10}=$ coeficiente de temperatura, $\mathrm{A}_{\max }=$ tasa máxima de fotosíntesis $\left(\mu \mathrm{mol} \mathrm{CO}_{2} \mathrm{~m}^{-2} \mathrm{~s}^{-1}\right), 95 \% \mathrm{~A}_{\max }$ and $50 \% \mathrm{~A}_{\max }=$ rango de temperaturas para el 95 y $50 \%$ de la tasa máxima fotosintética. Valores corresponden a los promedios $(n=5) \pm$ EE. Letras distintas indican diferencias estadísticas de acuerdo a prueba de Tukey

\begin{tabular}{lcccccc}
\hline Origin & Treatment & $\mathrm{T}_{\text {opt }}$ & $\mathrm{A}_{\max }$ & $95 \% \mathrm{~A}_{\max }$ & $50 \% \mathrm{~A}_{\max }$ & $\mathrm{Q}_{10}$ \\
\hline Antarctic & $15^{\circ} \mathrm{C}$ & $18.6 \pm 0.4^{\mathrm{a}}$ & $4.7 \pm 0.5^{\mathrm{a}}$ & $10.3-21.0^{\mathrm{a}}$ & $5.2-32.2^{\mathrm{a}}$ & $1.4 \pm 0.3^{\mathrm{a}}$ \\
& $4^{\circ} \mathrm{C}$ & $17.0 \pm 0.1^{\mathrm{b}}$ & $3.9 \pm 0.1^{\mathrm{b}}$ & $11.6-20.7^{\mathrm{a}}$ & $5.9-29^{\mathrm{b}}$ & $1.8 \pm 0.1^{\mathrm{b}}$ \\
\multirow{2}{*}{ Andes } & $15^{\circ} \mathrm{C}$ & $24.4 \pm 0.2^{\mathrm{c}}$ & $1.9 \pm 0.2^{\mathrm{c}}$ & $11.1-30.1^{\mathrm{b}}$ & $2.6-40.1^{\mathrm{c}}$ & $1.4 \pm 0.1^{\mathrm{c}}$ \\
& $4^{\circ} \mathrm{C}$ & $19.6 \pm 0.2^{\mathrm{d}}$ & $3.1 \pm 0.2^{\mathrm{d}}$ & $6.6-26.8^{\mathrm{b}}$ & $3.9-39.3^{\mathrm{d}}$ & $1.4 \pm 0.3^{\mathrm{c}}$ \\
\hline
\end{tabular}




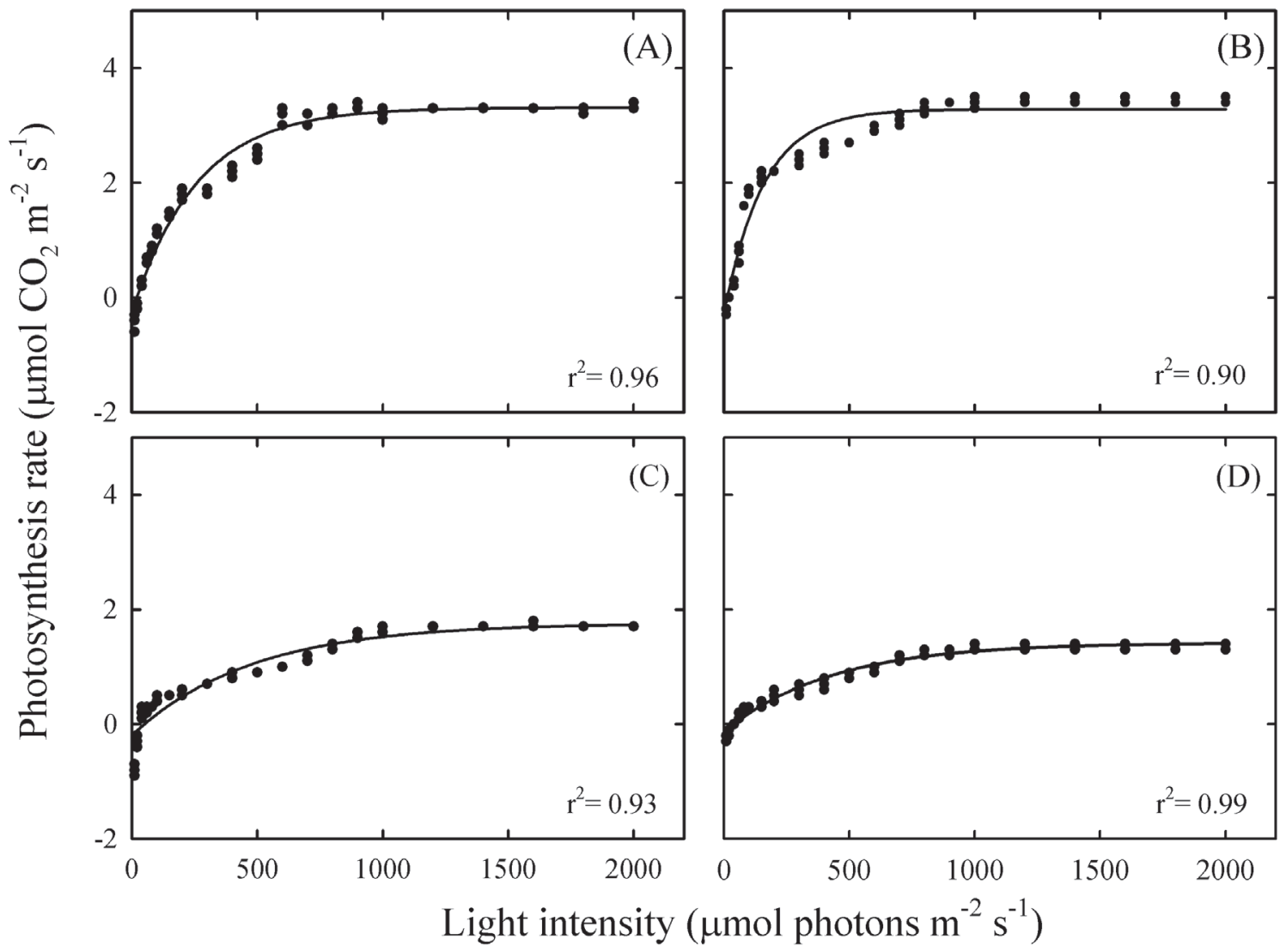

Fig. 2: Dependence of net photosynthesis on photosynthetic photon flux (PPFD) in Colobanthus quitensis. Net photosynthetic rates were measured in two populations of different origin (Antarctic and Andes) growing at $15{ }^{\circ} \mathrm{C}\left(250 \mu \mathrm{mol}\right.$ photons $\mathrm{m}^{-2} \mathrm{~s}^{-1}, 16 / 8$ day/night $)$ and after three weeks of low temperature treatments at $4{ }^{\circ} \mathrm{C}\left(250 \mu \mathrm{mol}\right.$ photons $\mathrm{m}^{-2} \mathrm{~s}^{-1}, 16 / 8 \mathrm{~h}$ day/night $)$ : Antarctic ecotype at $4{ }^{\circ} \mathrm{C}(\mathrm{A})$ and $15{ }^{\circ} \mathrm{C}(\mathrm{B})$, Andean ecotype at $4{ }^{\circ} \mathrm{C}(\mathrm{C})$ and at $15{ }^{\circ} \mathrm{C}(\mathrm{D})$.

Fotosíntesis neta dependiente de la densidad de flujo fotónico en Colobanthus quitensis. Las tasas de fotosíntesis neta fueron medidas en dos poblaciones de diferente origen (Antártica y Andes) crecidas a $15{ }^{\circ} \mathrm{C}\left(250 \mu \mathrm{mol}\right.$ fotones $\mathrm{m}^{-2} \mathrm{~s}^{-1}, 16 / 8$ día/noche) y después de ser tratadas a $4{ }^{\circ} \mathrm{C}$ durante tres semanas $\left(250 \mu\right.$ mol fotones $\mathrm{m}^{-2} \mathrm{~s}^{-1}, 16 / 8$ día/noche): ecotipo antártico a $4{ }^{\circ} \mathrm{C}(\mathrm{A})$ y $15{ }^{\circ} \mathrm{C}(\mathrm{B})$, ecotipo andino a $4{ }^{\circ} \mathrm{C}(\mathrm{C})$ y a $15{ }^{\circ} \mathrm{C}(\mathrm{D})$.

respectively. These results are in line with previous reports for arctic-alpine populations where the alpine showed higher optimum temperature for photosynthesis than the polar (Arctic) (Mooney \& Billings 1961, Mooney 1963, Mooney \& Johnson 1965, Björkman 1966, Körner 1999). Interestingly, after low temperature treatment, the optimum temperature for net photosynthesis changed in both plants groups, with this change being greater in the Andean plants, suggesting the ability to acclimation in both populations. Furthermore, plants from the Andes showed a $10{ }^{\circ} \mathrm{C}$ wider temperature range for net photosynthesis (95 and $50 \%$ of $\mathrm{A}_{\max }$ ) at both temperature regimes. These are important differences between both populations, which seem to be related with the prevalent microclimate conditions during the growing season. For instance, while in the Maritime Antarctic the daily average temperature during the growing season ranges from $-2-6{ }^{\circ} \mathrm{C}$, the Andean values range from $0-22{ }^{\circ} \mathrm{C}$, suggesting that the Andean plants must adjust their photosynthetis to a warmer and wider thermal environment compared to the Antarctic plants. While plants in the Andes need to increase the stability of their photosynthetic apparatus to high temperature, plants in the Antarctic must increase their ability to maintain the enzymatic 
processes of photosynthesis at low temperature (Berry \& Björkman 1980). Sensitivity of Antarctic Colobanthus quitensis to low temperatures can be observed in its $\mathrm{Q}_{10}$ values at $4{ }^{\circ} \mathrm{C}$, where the higher values suggest an intrinsic higher capacity to take advantage of small increases in the ambient temperature by quickly increasing their photosynthesis. In herbaceous winter annuals, an enhancement of photosynthesis and changes in respiratory metabolism has been shown to have a positive balance during the cold season (Ensminger et al. 2006).

Regarding the Antarctic Colobanthus quitensis, the optimum temperature registered in our study was higher than those reported for this species growing in the Stepping Stones Islands near to the Palmer Station in the west coast of the Antarctic Peninsula $\left(14{ }^{\circ} \mathrm{C}\right.$, Xiong et al. 1999). These differences may be due to the fact that the cited authors worked with plants from further south than our collection site in the Antarctic and that our plants grew at lower PPFD. However, our values are similar to those reported by Edwards \& Smith (1988) from studies carried out under controlled conditions $\left(19{ }^{\circ} \mathrm{C}\right) . \mathrm{P}_{\mathrm{n}}$ rates obtained here for both populations of $C$. quitensis never reached the value reported by Xiong et al. (1999), which was $8.2 \mu \mathrm{mol} \mathrm{CO}_{2} \mathrm{~m}^{-2} \mathrm{~s}^{-1}$ at $14{ }^{\circ} \mathrm{C}$. We suggest, that the differences are related with the growing conditions of our plants in the laboratory (low PPFD) that can affect the photosynthesis rate. Nevertheless, $P_{n}$ values obtained in our study for individuals from the Andes under controlled conditions coincide with field measurements taken for $C$. quitensis in La Parva, where values between 2.0-4.5 $\mu \mathrm{mol} \mathrm{CO} \mathrm{Cm}^{-2} \mathrm{~s}^{-1}$ were registered during diurnal courses (Casanova-Katny et al. 2006). Clearly, plants from the Antarctic present higher $\mathrm{A}_{\max }$ values than those from the Andes. We suggest that the first group increases the photosynthesis rate when the air temperature reaches values near to the optimum, taking advantage from every warmer day during the short growth season.

Photosynthetic responses to PPFD also differed between populations. Both, $I_{c}$ and $I_{s}$, were higher in the Andean population and that these parameters changed in both plant groups after a low temperature treatment. $I_{c}$ values were slightly lower compared with Colobanthus growing in the field (150-200 $\mu$ mol photons $\mathrm{m}^{-2} \mathrm{~s}^{-1}$ at $4-12{ }^{\circ} \mathrm{C}$ ), while $\mathrm{I}_{\mathrm{s}}$ values found here were lower in the Antarctic plant and higher in the Andean compared with the level presented by Xiong et al. (1999) (750 to $800 \mu \mathrm{mol}$ photons $\mathrm{m}^{-2} \mathrm{~s}^{-1}$ at $4-12{ }^{\circ} \mathrm{C}$ ). However, measurements for both temperature treatments were carried out only at room temperature and these values could change if

TABLE 2

Photosynthetic parameters obtained from light responses curves in two populations of Colobanthus quitensis of different origin (Antarctic and Andes). Plants were growing at $15^{\circ} \mathrm{C}(250 \mu \mathrm{mol}$ photons $\left.\mathrm{m}^{-2} \mathrm{~s}^{-1}, 16 / 8 \mathrm{day} / \mathrm{night}\right)$ and after three weeks of low temperature treatments at $4{ }^{\circ} \mathrm{C}(250$ $\mu \mathrm{mol}$ photons $\mathrm{m}^{-2} \mathrm{~s}^{-1}, 16 / 8 \mathrm{~h}$ day/night $): \mathrm{I}_{\mathrm{c}}=$ light compensation points $\left(\mu \mathrm{mol}\right.$ photons $\left.\mathrm{m}^{-2} \mathrm{~s}^{-1}\right), \mathrm{I}_{\mathrm{s}}=$ light saturation points ( $\mu$ mol photons $\left.\mathrm{m}^{-2} \mathrm{~s}^{-1}\right), \mathrm{A}_{\max }=$ maximum photosynthetic rate $\left(\mu \mathrm{mol} \mathrm{CO}_{2} \mathrm{~m}^{-2}\right.$ $\left.\mathrm{s}^{-1}\right) ; \mathrm{Rd}=$ dark respiration $\left(\mu \mathrm{mol} \mathrm{CO} \mathrm{CO}^{-2} \mathrm{~s}^{-1}\right)$. Values are means $\pm \mathrm{SE}(\mathrm{n}=5)$. Different letters indicate statistical differences after Tukey-tests

Parámetros fotosintéticos obtenidos de las curvas de respuesta a la luz en dos poblaciones de Colobanthus quitensis de diferente origen (Antártida y Andes). Las plantas fueron crecidas a $15^{\circ} \mathrm{C}\left(250 \mu \mathrm{mol}\right.$ fotones $\mathrm{m}^{-2} \mathrm{~s}^{-1}, 16 / 8 \mathrm{~h}$ día/noche $)$ y luego expuestas a tres semanas de tratamiento de baja temperatura a $4{ }^{\circ} \mathrm{C}\left(250 \mu\right.$ mol fotones $\mathrm{m}^{-2} \mathrm{~s}^{-1}, 16 / 8 \mathrm{~h}$ día/noche $)$. $\mathrm{I}_{\mathrm{c}}=$ punto de compensación lumínica ( $\mu \mathrm{mol}$ fotones $\mathrm{m}^{-2} \mathrm{~s}^{-1}$ ), $\mathrm{I}_{\mathrm{s}}=$ punto de saturación lumínica ( $\mu$ mol fotones $\left.\mathrm{m}^{-2} \mathrm{~s}^{-1}\right), \mathrm{A}_{\max }=$ tasa máxima de fotosíntesis $\left(\mu \mathrm{mol} \mathrm{CO}_{2} \mathrm{~m}^{-2} \mathrm{~s}^{-1}\right), \mathrm{Rd}=$ respiración oscura $\left(\mu \mathrm{mol} \mathrm{CO}_{2} \mathrm{~m}^{-2} \mathrm{~s}^{-1}\right)$. Valores corresponden a los promedios $(n=5) \pm$ EE. Letras distintas indican diferencias estadísticas después de la prueba de Tukey

\begin{tabular}{lccccc}
\hline Origin & Treatment & $\mathrm{I}_{\mathrm{c}}$ & $\mathrm{I}_{\mathrm{s}}$ & $\mathrm{A}_{\max }$ & $\mathrm{R}_{\mathrm{d}}$ \\
\hline \multirow{2}{*}{ Antarctic } & $15^{\circ} \mathrm{C}$ & $43 \pm 1.7^{\mathrm{a}}$ & $700 \pm 3.4^{\mathrm{a}}$ & $3.4 \pm 0.1^{\mathrm{a}}$ & $-2.6 \pm 0.3^{\mathrm{a}}$ \\
& $4^{\circ} \mathrm{C}$ & $47 \pm 1.6^{\mathrm{b}}$ & $600 \pm 12.3^{\mathrm{b}}$ & $2.9 \pm 0.2^{\mathrm{a}}$ & $-1.1 \pm 0.1^{\mathrm{c}}$ \\
\multirow{2}{*}{ Andes } & $15^{\circ} \mathrm{C}$ & $77 \pm 1.6^{\mathrm{c}}$ & $900 \pm 2.5^{\mathrm{c}}$ & $1.4 \pm 0.1^{\mathrm{b}}$ & $-0.6 \pm 0.0^{\mathrm{b}}$ \\
& $4^{\circ} \mathrm{C}$ & $80 \pm 4.1^{\mathrm{d}}$ & $1000 \pm 1.6^{\mathrm{d}}$ & $1.7 \pm 0.1^{\mathrm{c}}$ & $-2.5 \pm 1.5^{\mathrm{a}}$ \\
\hline
\end{tabular}


they would be taken at lower temperatures. Nevertheless, our results demonstrate marked differences in light requirements between Antarctic and Andean populations of $C$. quitensis. This is consistent with the observation of predominantly higher PPFD in the Andes (La Parva) during the entire growing season, where monthly average of PPFD values of about 1,000 $\mu \mathrm{mol}$ photons $\mathrm{m}^{-2} \mathrm{~s}^{-1}$ (with high values of $2,000 \mu \mathrm{mol}$ photons $\mathrm{m}^{-2} \mathrm{~s}^{-1}$ ) have been registered during the growing season with only scarce occurrence of overcast conditions (Casanova-Katny et al. 2006). In sharp contrast, in the Maritime Antarctic cloudiness and overcast conditions are frequent (about 80 $\%$ days of the growing season), where low PPFD has been reported by Xiong et al. (1999) and Xiong \& Day (2001). Our results suggests that Andean individuals are not light-limited as has been indicated for other alpine plants, which are frequently shaded by overcast conditions during the summer (Körner 1999). Moreover, dark respiration rates showed different tendencies between both ecotypes. While in the Antarctic plants $R_{d}$ decreased (more than $50 \%$ ) after low temperature treatment, in the Andean ecotype an increase was found (Table 2). This suggests that in the cold short Antarctic growing season, plants must be able to ajust the metabolism to maintain low respiratory loss at low temperature, which is coincident with the positive $P_{n}$ rates at the same conditions. In contrast, in the Andes, plant metabolism can not maintain low $\mathrm{R}_{\mathrm{d}}$ at low temperature, because plants present higher temperature optimum for Pn, which is related to the prevalent warmer climatic conditions (Casanova-Katny et al. 2006).

The differences found in the photosynthetic parameters studied here for two populations of Colobanthus quitensis suggest an ecotypic differentiation between the alpine (Andes) and polar populations (maritime Antarctic) which is in agreement with the morphological differentiation (differences in leaf size, shape and peduncle length) reported by Gianoli et al. (2004) for the same plant groups. Clearly, both populations are well adapted to the prevailing microclimate conditions of their environment, where the Andes ecotype showed higher temperature optimum and light saturation points than the Antarctic ecotype. Thus, our results highlight the adaptations of the photosynthetic apparatus of alpine and Antarctic populations of the same species to their prevailing environment. However, Chapin \& Oechel (1983) did not find differences in photosynthesis between arctic and alpine populations of Carex aquatilis, suggesting that adjustment of photosynthesis to the prevailing climate is not universal. Nonetheless, Chapin \& Oechel (1983) reported important differences in the intrinsic rate of growth between arctic and alpine populations of Carex aquatilis, a phenomenon also reported for $C$. quitensis (Gianoli et al. 2004), indicating that there is a gamut of attributes enabling species to adapt to their abiotic environment.

\section{ACKNOWLEDGEMENTS}

This study was funded by FONDECYT 1010899. M. Angélica Casanova-Katny thanks to MECESUP UCO 0214, which provided funds for her postdoctoral position. This paper forms part of the research activities of the Institute of Ecology and Biodiversity (IEB) supported by Grant No. P05-002-F ICM. BBVA prize for Conservation of Biodiversity in Latin-American 2004 is also acknowledged.

\section{LITERATURE CITED}

ALBERDI M, LA BRAVO, A GUTIÉRREZ, M GIDEKEL \& LJ CORCUERA (2002) Ecophysiology of Antarctic vascular plants. Physiologia Plantarum 115: 479-486

BERRY J \& O BJÖRKMAN (1980) Photosynthetic response and adaptation to temperature in higher plants. Annual Review of Plant Physiology and Plant Molecular Biology 31: 491-543.

BILLINGS WD \& HA MOONEY (1968) The ecology of arctic and alpine plants. Biological Reviews of the Cambridge Philosophical Society 43: 4-529.

BJÖRKMAN O (1966) Comparative studies of photosynthesis and respiration in ecological races. Brittonia 18: 214-224.

BLISS LC (1971) Arctic and alpine plant life cycles. Annual Review of Ecology and Systematics 2: 405-438.

BLISS LC (1956) A comparison of plant development in microenvironments of arctic and alpine tundras. Ecological Monographs 26: 303-337.

CASANOVA-KATNY MA, LA BRAVO, M MOLINAMONTENEGRO, LJ CORCUERA \& LA CAVIERES (2006) Photosynthetic performance of Colobanthus quitensis (Kunth) Bartl. (Caryophyllaceae) in a highelevation site of the Andes of central Chile. Revista Chilena de Historia Natural 79: 41-53.

CAVIERES LA, A PEÑALOZA \& MTK ARROYO (2000) 
Altitudinal vegetation belts in the high-Andes of central Chile $\left(33^{\circ} \mathrm{S}\right)$. Revista Chilena de Historia Natural 73: 331-344.

CHAPIN III FS \& WC OECHEL (1983) Photosynthesis, respiration and phosphate absorption by Carex aquatilis ecotypes along latitudinal and local environmental gradients. Ecology 64: 743-751.

DAY TA, CT RUHLAND, CV GROVE \& FS XIONG (1999) Growth and reproduction of Antarctic vascular plants in response to warming and UV radiation reductions in the field. Oecologia 119: 24-5.

EDWARDS JA RIL SMITH (1988) Photosynthesis and respiration of Colobanthus quitensis and Deschampsia antarctica from the maritime Antarctic. British Antarctic Survey Bulletin 81: 4363

ESMINGER I, F BUSCH \& NPA HUNER (2006) Photostasis and cold acclimation: sensing low temperature through photosynthesis. Physiologia Plantarum 126: 28-44.

FRIEND AD \& FI WOODWARD (1990) Evolutionary and ecophysiological responses of mountain plants to the growing season environment. Advances in Ecological Research 20: 60-124.

GIANOLI E, A ZÚÑIGA-FEEST, M REYES-DÍAZ, LA CAVIERES, LA BRAVO \& LJ CORCUERA (2004) Ecotypic differentiation in morphology and cold resistance in populations of Colobanthus quitensis (Cariophyllaceae) from the Andes of central Chile and the maritime Antarctic. Arctic, Antarctic Alpine Research (USA) 36: 470-475

GRAVES JD \& K TAYLOR (1988) A comparative study of Geum rivale $L$. and $G$. urbanum $L$. to determine those factors controlling their altitudinal distribution. II. Photosynthesis and respiration. New Phytologist 108: 297-304.

HOFFMANN A, MTK ARROYO, F LIBERONA, M MUÑOZ \& J WATSON (1998) Plantas alto-andinas en la flora silvestre de Chile. Ediciones Claudio Gay, Santiago, Chile. 281 pp.

KAPPEN L (1999) Pflanzen und Mikroorganismen in der Polarregionen. 30 Jahre deutsche Beiträge zur Polarforschung. Naturwissenschaftliche Rundschau 52: $174-183$.

KÖRNER C (1999) Alpine plant life. Functional plant ecology of high mountain ecosystems. SpringerVerlag, Berlin, Germany. 338 pp

KÖRNER C \& M DIEMER (1987) In situ photosynthetic responses to light, temperature and carbon dioxide in herbaceous plants from low and high altitude. Functional Ecology 1: 179-194.

LAMBERS H, SF CHAPIN III \& TL PONS (1998) Plant physiological ecology. Springer-Verlag, New York, New York, USA. 540 pp.

Associate Editor: Thomas Kitzberger

Received October 19, 2006; accepted March 14, 2007
MCNAUGHTON SJ, CAMPBELL RS, FREYER RA, MYLROIE JE \& KD RODLAND (1974) Photosynthetic properties and root chilling responses of altitudinal ecotypes of Typha latifolia. Ecology 55: 168-172.

MOHR H \& P SCHOPFER (1995) Plant physiology. Springer-Verlag, Berlin, Germany. 629 pp.

MOONEY HA (1963) Physiological ecology of coastal, subalpine, and alpine populations of Polygonum bistortoides. Ecology 44: 812-816.

MOONEY HA \& WD BILLINGS (1961) Comparative physiological ecology of arctic and alpine populations of Oxyria digyna. Ecological Monographs 31: 1-29

MOONEY HA \& AW JOHNSON (1965) Comparative physiological ecology of an arctic and alpine population of Thalictrum alpinum L. Ecology 46: 721-727.

MOONEY HA \& M WEST (1964) Photosynthetic acclimation of plants of diverse origin. American Journal of Botany 51: 825-827.

MOORE DM (1970) Studies in Colobanthus quitensis (Kunth) Bartl. and Deschampsia antarctica Desv.: taxonomy, distribution and relationships. British Antarctic Survey Bulletin 23: 63-80.

OSMOND CB (1994) What is photoinhibition? Some insights from comparisons of shade and sun plants. In: Baker NR \& JR Bowyer (eds) Photoinhibition of photosynthesis from molecular mechanisms to the fields: 1-24. Bios Scientific Publisher Limited, Oxford, United Kingdom.

PISEK A, W LARCHER, A VEGIS \& K NAPP-ZINN (1973) The normal temperature range. In: Precht H, J Christophersen, H Hensel \& W Larcher (eds) Temperature and life: 102-194. Springer, Berlin, Germany.

SMITH RIL (2003) The enigma of Colobanthus quitensis and Deschampsia antarctica in Antarctica. In: Huiskes AHL, WWC Gieskes, J Rozema, RML Scorno, SM van der Vies \& WJ Wolf (eds) Antarctic biology in a global context: 234-239. Backhuys Publisher, Leiden, The Netherlands.

XIONG FS \& TA DAY (2001) Effect of solar ultraviolet-B radiation during springtime ozone depletion on photosynthesis and biomass production of Antarctic vascular plants. Plant Physiology 125: 738-751.

XIONG FS, CT RUHLAND \& TA DAY (1999) Photosynthetic temperature response of the antarctic vascular plants: Colobanthus quitensis and Deschampsia antarctica. Physiologia Plantarum 106: 276-286.

XIONG FS, CT RUHLAND \& TA DAY (2000) Photosynthetic and respiratory acclimation and growth response of Antarctic vascular plants to contrasting temperature regimes. American Journal of Botany 87: 700-710. 
